Valiyeva F.,

\title{
DEGREES OF SEIR SULUK AND SALIK ON THE WAY TO DIVINE LOVE IN TURKISH POETRY OF THE XIII-XV CENTURIES
}

\begin{abstract}
Summary. The article deals with specific features of medieval Sufi poets. Many traditional approaches from the Sufi studiesare clarified. The struggles of Salik (selfpurified person) in the paths passed by him in love to reach the perfection level are described.

Contemplation and silence are integral parts of the Unit, their role to reach the divine love are also amongst problems analyzed in this paper. This article touches upon the matter that Salik leaves the ignorance and joins the science while his spiritual journey, then he is oriented towards the good morals from evil deeds. These spiritual passages are clarified also in this paper. The first degree of Salik is the $i$-illah, the second journey is $i$-fillah, the third is $i$-ma-Allah and the fourth is the degree of the seyri-Anillah that the conditions of reaching these levels are investigated in the article. It is noted that the moment of Anillah, the fourth degree of Salik, means the occurrence of orienting toward the kesret/plenty. In Sufism, the definition kesret expresses the meaning of abundance, i.e. the reverse side of Unit. In this article it is pointed out that two of the four spiritual journeys are attributed to God's righteousness and that Salik is able to reach this point, then the question of Salik's acquittal in the last two journeys is being investigated. There are also some distinct views on seyri-suluk (spiritual journey) contained in the article. The names of Salik's qualify, reflected in poems, have been cited as examples. The matter of assistance of Murshid (teacher) in the stage of preparation for SeyriSuluk (Spiritual journey). Obviously, the main purpose of Suluk (journey) in the Tasawwuf is to gain highspiritual qualities, to purify his soul and to obtain positive dignities in order to reach the truth so that the article analyzes the ways of this kind of purification based on thoughts of the Sufi poets. According to Tasawwuf ideas, the ways to the truth is so much more than the stars in the sky and breath of people. The article investigates the very interesting moment that Saliks' purposeare common, but the path they pass are different. The texts concerning the closeness of human kind, integral part of the God according to the studies of Tasawwuf, alike the other beings have also been cited as examples in this article. It is known that the love appreciates the human being as the most magnificent of all beings and assists him to be at the summit of high qualities. This definition of raising is a deep intellectual, spiritual and emotional stage not going into any geographical definition. The typological parallels made by and between the 13-15-th centuries' Turkish mystical poets and Oriental classic poets create an overall outcome, allowing different and similar features to be found in the article. As the subject of love can express secular and irrational features, with the help of this journey the Salik leaves behind the deficiencies and reaches the spiritual maturity.
\end{abstract}

Key words: Suluk, Salik, moral, Tasawwuf, mind, unity.
Introduction. Not only in medieval thinking, but in every human history, each sect, organization, or different religious and literary tendency, in addition to having their own teachings, different points of view of ways of expression, they also have different styles. From this point of view, Sufi teaching has its own characteristics, as well as such sacred aspects as the degrees of Seir Suluk and Salik. In the poetry of Sufi poets of the thirteenth and fifteenth centuries, these subtleties are accompanied in the form of ideal learning.

\section{Bulartn yollart erkant budur}

Süluk-i vahdetün seyranı budur. [1, p. 36]

The famous poet of the 15th century, Kamal Ummi, who managed to collect intellectuals around the world, like other believers, was able to interpret with great skill the past stages, the degrees of Salik achieved in his poetry.

As is known from medieval Sufi poetry, there are certain ways, stages and moments in Sufi teaching to possess a sense of love and to be in the presence of God, dissolving in it, reunite with it.

\section{Dilersin la mekana irişesin sen}

Seyr u sefer kil yüri mekanını terk et [1, p. 211]

Discussion. The poet, who, unlike many secularists, emphasizes the expressions of Seir Suluk as "seir travel," he was able to master all aspects of this path of love in his poetry. Suluk is essentially a road, and "sair and suluk" means to follow the path, observe, seek and learn. As the devotees say, this is the path of love, because it was divine love that pushed Salik to going by this intense way. Of course, sair suluk is a sign of a whole way of lifestyle. Nevertheless, Seir Suluk is primarily a path aimed at uniting divine love, which has values associated with upbringing in Sufi teachings. Araidin, author of Sufism and Sect, emphasizes an interesting analogy with the Suluk: There is no traveler without reading and wandering, and there is no way to Sufism without struggle and muraqabah [2]. Araydin's thoughts also reflect the thoughts of Sufi poets of the 13-15 centuries on this subject. Suluk is a controversial way to achieve existence. Of course, those who likened their student life to sair and suluk assumed a scientific debate, the result of patience, being able to endure difficulties, endure and receive high degrees. According to Sufi views, Sayre is the departure of Suluk from ignorance in order to go to science, to refrain from everything bad, and to follow good morality and move from his being to the truth [1, p. 211].

The guide of the seir suluk sect is the absolute being - God. Medieval poetry underscores the idea that God opens this path and that Suluk cannot walk this path alone.

$$
\begin{aligned}
& \text { İy yolun hamisi mülkün maliki } \\
& \text { Sen yetişdür menzile her saliki [1, p. 212] }
\end{aligned}
$$


Kemal Ummi, like other poets of mysticism, shows that the realization of the goal ends with the achievement of Salik housing, and the first condition for the Suluk is to cleanse oneself, to free oneself from indulgence internally, from the dirt of the world, to look away even from the smallest particle of the world. Crossing this road, Salik should try not to take the burdens of peace on his shoulder. Thus, the human body must be light, beautiful, pure and holy, so only by this way people can reach housing. Note:

Hic yol eri ağgr yükle menzile yetmez

Yükdürşer ü can dahisebük-bar gerekdür

Kaydunukeski, menzileyitesin

Çün ağıryüklüler yola döymez [1, p. 212]

According to Kamal Ummi, who created in the light of theoretical expressions of Sufi philosophy, those who adhere to negative emotions, such as passion, greed, deception, cannot become Saliks. Since at this time the severity of all this negativity will not allow him to travel. The poet emphasizes that, going out onto the road, you should not even look at the painting beauty, give up temptations, otherwise this road will close for you forever.

\section{Bir kila kilma nazar kalma girü}

Yohsa baglar yolunu o ince kil [1, p. 212]

In addition to moral purification in mystical thinking, mental discharge is also one of the most important prerequisites. The explanation of this issue is more often found in verses of the 15th-century Sufi poet Kamala Ummi. Kamal Ummi also notes those who stumble along the way, citing even the gravity of a tiny needle, for the worldly good, and indicates why they remain motionless in a particular place.

Yüküni yeynildi gör i yol eri

\section{Kim Mesihe ignesi oldi sakil [1, p. 213]}

Each suffix who develops the concept of a perfect person can better understand the subtleties of this path and explain it to the reader more clearly in poetic language. Because the value that time gives to poetry and art is the most compelling reason why they choose this path.

\section{Ahiret devletlerine dünyeden kaçan yiter}

Yolu koyub kula uyan menzile kacan yiter [1, p. 212]

The aspirant who draws lessons from the Sufi doctrine, with his scientific, religious and intellectual thinking on the path to love, passes through the suluk like a murid, and after a while becomes a murshid. This idea is found in the works of all Sufis.

\section{Hin bir Gülşanivas Röışanidon}

\section{Süluk seyri bilmiş sahibi-ətvar [6, p. 91]}

As Gulshani Barda notes, at that time, along with travel difficulties, she was called suluk, and during this period of her observation she was called sair. Salik watches his paths, and God watches him. If the applicant who starts the sair with the suluk does not go through these difficulties, then he will not be able to become a Salik. According to Sufi poets of the thirteenth and fifteenth centuries, sair and suluk are not the same in the life of every person. There is a person who can go this route for forty days, and there are those who can go this road for several years. Kemal Ummi, like all his like-minded people, repeatedly insists that those who do not leave the world cannot follow this path.

\section{Bu yola canlulardan kimse varmaz}

Veli cansuz gelenlere saladur [1, p. 211]

Guardianship is the achievement of friendship with the Almighty, and the poet explains that trusteeship belongs only to those who are in the spell of heaven.
According to many Sufi poets, first of all, along with the power of love, it is important that the mind and heart play an important role along this path. Amateurs also believe that in the world of Sufism, the mind and heart must help each other in order to achieve the truth. Even Sufis believe that if a person has a defect or deficiency in his mind and soul, he cannot open his wings in the sky and cannot achieve perfection. Here, in addition to the fact that sair's means to go its own way, it is also a mystical term representing a spiritual journey. Sayr and Suluk can penetrate any person, having undergone special training with a murshid or subjecting himself only to this path. However, some religious scholars believe that this path can only be achieved with the help of murshids.

Consider the following examples of Yunus Emre:

Tapduğun tapusunda, kul olduk qapusinda,

Yunus miskin cı̆̆gldı bişdi elhamdï lillah [3, p. 11]

Yunus Emre points out that he worked with Murshid Tapdyg before he reached the Seir Suluk (this path), and then went on this sacred and blessed journey. He begins this path as a contender and after development continues it as a Salik. The poet also explains that every Salik on the path of the Suluk should refrain from worldly pleasures, close his eyes to worldly blessings and refrain from all bad habits in order to gain the power of reverence for divine love.

From the content of his poems it is clear that the Sufis are most often on two aspects of the seir on the path of this magnificent love. The first of them is called "sair nuzuli", and the second is called "sair uruchi". In seir nusul this means "sair descent", and this sair is beyond existence. In other words, this is the slightest tilt of the kull in the nosil. That is, the landing of the deity Ahadiya (loneliness) at the stage of the multitude. From the point of view of the Sufi, man in the world of beings is a phenomenon of the result of the sair. This point of view is better understood in the hymns of Haji Bektas Veli. However, there is a difference between Haji Veli Bektas and other devoted mystical poets.

\section{Dürüst eylerse kul bu kirk maqamı \\ Oror Hakka gider gönlü sakamı \\ Onuna hükm eder anin Şeriat \\ Tarikat onuna kilar suruat}

Onunu Marifet zabt eyler ey yar

Onu da Haklkatindır kil izhar [4, p. 222]

The poet notes that there are forty-five points in the path of the Salik and difficulties such as passing through four doors. Each of the four doors is associated with ten points. That is, at the entrance to the Sharia there are ten points, at the door of the sect - ten, at the door of courtesy - ten, at the door of truth - ten which Salik must pass. All this occupies a large place in the work of Sufi poets. Both the poems of Haji Veli Bektas [3, p. 89] and the poems of Kemal Ummi clarify these problems and explain them with great skill $[1$, p. 215].

The poet writes about the first gate of the Sufi path - Sharia:

\section{Seriat kullara Hakdan otadir}

Seriatsiz, kullar hep filler hep hatadir [4, p. 228]

Even the Kamal Ummah, which confirms these thoughts, indicates that those who follow Sharia do not suffer from mental pain: the first basic rule of Islam, the first stage of the Sufi path and the first door are Sharia.

\section{İ hakikatden dem uran bi şeri at, urma laf}

Şeri koyup bidate uyan zria gümrah olur [1, p. 210]

It is impossible to approach other moments and doors without knowing Sharia. 


\section{Şeriat bilmedin muhkem hakkatden ururam dem}

Kuru laf ürürem her dem ki, bir dona - yi esraram [1, p. 210]

Kamal Ummah, like other secular poets, suggests that Salik can thus go through the third door of courtesy and through the fourth door of truth. Although the location of these doors is different in most sources, Haji Veli repeatedly insists that the door of courtesy in the works of Kemal Ummi is in front of the door of truth. These degrees are listed as follows.

The first stage for Salik is seir i-illah, the second seir i-allah, the third seir i-ma Allah, and the fourth seir i-Anilah. (2, Internet summary) Interestingly, in the comments, the Sufis who list these four steps, the idea is the same, but the style of expression is different. Even Kamal Ummi, one of the southeastern poets of the 15th century, points out that the seir i-phillah is the separation of Salik from the attributes of humanity, thought and mathematics. And Bekabillah is the place of the moment where the Salik unites with God after Fenafillah. At this moment, the appearance of the Salik as in a drop of a mosque means its union with the Vahdat Sea [1, p. 215]. However, the poet gives the names of these degrees either in abbreviated form or in various styles. Despite all this, the suffix, who explains the four stages, describes Salik's responsibilities on the divine path to reaching the stages and shows that the journey to God begins at the first stage and the feeling of temptation must prevail in order to reach this stage. To complete the journey, a sense of multitude and unity must be understood. A person who leaves the room of temptation goes to the stage where he begins to observe God.

That is, the spiritual journey begins. In this journey, the Salik disappears in God, thereby moving to the level of Fenafillah [1, p. 215-216].

\section{Sidkla fakr u fena yolina azm etdüise}

Ne işündür, senün ayruk beg ü ispahi gönül $[1, p .216]$

The poet also reminds the reader of the work of Attar Mentigiteir, at the moment when the Salik reaches the phase of Fenafillah, that is, it unites itself with its friend.

\section{Kimse hic Simurqa irmez uymayınca hüdhüde}

Pes ne bilsün degme kuş kim kancarudur kuhi- kaf [1, p. 216]

Almost all Sufi poets of the XIII-XV centuries finish their attitude to this issue with the moment of reunion with God. In their opinion, the second stage of the spiritual journey is called seir $\mathrm{i}$-phillah. This divine love is seen as a concept of travel in God. Here, all the features of God are revealed to Salik. In this way, all human life disappears, and the secrets and truths known as "Elm-Ledun" are revealed. Salik reaches this state of existence in the so-called becabillah stage. This point is more clearly explained in the work of "Garibname" of Ashig Pasha:

Yol varasan seyran-u cevlan ile

Hec gümansız iresin o menzile

İsbu sözden maksudumuz kaz degil [1, p. 53]

Ibrahim Gulshani describes the third stage of the Seir Suluk where Salik reaches the moment of a journey with God:

Yeri, gögdo hər na var günbandovï camid, nəbat,

Dövra göra seyr edorlor saliki atvar mast [6, p. 45]

Ashik Pasha shows that during this sair the twins disappear. Salik joins the Divine Unity (Ahadiya). It is even claimed that this point was counted by the sages as two summers.

Ikiliksiz birlik ile yar ile

Yarmığ bașarmuyasın ar ile

Yarliq ile Hak yoluna giresin

Birlik ile hak dizarın göresin [5, p. 49]
At the fourth stage of this divine journey, there is a saire anialah, that is, the point of travel from God. At this moment, God regulates the path of the ascending Salika and directs it from the multitude to the unity.

Vohdotin camindon olmuş kasrot asrüp sərbasor

Qalmaylb aylq na isa oluban yekbar mast [6, p. 45]

At this moment, existence begins from nothing. Salik comes to his senses, and reaching the power of murshid again enter to the multitude (among people).

This topic is also interesting, expressed in the works of Gulshani Bardai. His works reflect all aspects of the world of multitude and unity.

\section{Binahayat kasrot ilo vahdotün}

\section{Dövr ilo seyran, bişu kam nodir. [6, p. 80]}

There are several conditions of the moment, that is, during his first journey of love (the first and second stage), Salik usually gets a degree of rapprochement (led), that is, friendship with God, and at the second and third moment he receives a degree of murshid. People of this path - in an unconscious sense - are now able to combine all their perfect qualities, and this is the sole purpose of Sufi teaching.

Yol erenleri göcüp yola girdi

Döke yortr ahir dünbeki servan

Usan olma , başuna aklunu der

Yol uzakdur, ki yokdur hadd u payan [7, p. 4]

Ahmed Fakih also explains that Salik can reach God only after he can unite many qualities. Salik should concentrate these traits into himself along the path of sair and suluk. Here, traits such as enlightenment, spiritual purification, sanctify Salik. Such an approach and Salik degrees are reflected in the work of most devoted poets. The brightness of the human heart, the radiant nobility of noble deeds and moral regulation, and similar features, were the main creative criteria of philosophers of the 13-15 centuries. In fact, sair and suluk are regarded by Suf poets as a teaching method. This path begins with the seir of the mind and heart, and then wings open to the sky. In the verses of Kemal Ummi, he explains these points in detail with separate headings. Sulukam: "Salik, the path along which Salik goes, and advice in the method, attention is paid in the name of Salik to whom the name of the intermediary is learned" [1, p. 211].

\section{Dilersen la -mekana irişesen sen}

\section{Seyri-sefer kll yüri mekanünü terk et $[1, p .211]$}

Kamal Ummi, popular in the 15th century and known as one of the most famous poets, explains that the goal here is to leave space and reach the point of meaninglessness. According to the poet, the murshid who embarked on this path should repent. He should take into account the advice in every case and respect the advice of those older than him. A wanderer reaching the summit during a suluk watches as a bird of Huma out of space.

Her nefes canum humasu la mekan seyrin kilur

Gerci nefsum baykuşu gicmedi bu viraneden [1, p. 212]

The poet does not lose sight of the consolation, the traveler who passes from difficult moments.

\section{Gahi agar işi kibi göklere seyr ider gögi}

Gahi yiri Yusiflayın ziri ü zemin ü gah olur [1, p. 212]

Results. The Salik completes his suluk in a secluded and isolated form, and thus attains the degree of fanafillas, the poet describes as a drowning point in water. This is described as the combination of a drop with the sea in the work of Sultan Weled or the disappearance 
of darkness in the sun in the work of Gulshahri. Occupying a special place in the work of the 15th century, Kamal Umm, in his poems pays attention to all kinds of moments of safic views, reflecting all shades of mysticism. In his writings, the path of Seir Suluk and Salik is fully revealed, and many highlights on this road are highlighted. From the content of all the statements made by Seir Suluk, we can conclude that the teaching of Sufism is a great moral theory. That is, it is realized and conceptualized in accordance with the requirements of this period of study, which seeks to combine such qualities as perfection, justice, peace, friendship, fraternity, mercy, generosity and so on. Kamal Umm, as a Sufi poet, skillfully uses this concept to inspire his readers.

\section{References:}

1. Kamal Ümmi haz.Yrd. Doc.Dr. Hayati Yavuzer. Bolu Araşdırmalar Merkezi Ankara 2013.

2. İnternet rezus Eraydın Selcuk, Tasavvuf ve Tarikatler, Marifet yay. İstanbul 1981, səh. 30

3. Yunus Әmrə Risalat al-Nüshiyya və Divan, Ac. Gölpinarlı A. Eskişehir Turizm ve Tanıtma dergisi yayını, İstanbul 1965, $310 \mathrm{~s}$.

4. Makalat-1 Hacı Bektaşı Veli, haz. M. Elşad Coşan, İstanbul 2013,

5. Aşık Paşa -yı Veli Garibname cev. Doc. Dr. Bedri noyan Ardıc yayınları Ankara1998, səh 422.

6. Şeyx İbrahim Gülşəni Bərdəi Divan Avrasiya Press, Bakı 2006, səh.416.

7. Ahmed Fakih Çarhname haz. Mecdut Mansuroğlu Pulhan matbaası İstanbul 1956 səh.11.

Велісва Ф. Етапи Сейра Сулука і випробування Салика на шляху до божественної любові

Анотація. Тему статті складають специфічні особливості суфійського вчення середньовіччя. Робляться спроби прояснити багато теоретичних аспектів, пов'язаних iз зазначеним плином. Описуються етапи боротьби, яку повинен був вести Салик (мандрівник, що відноситься до певної релігійної секти, що йде праведним шляхом) заради досягнення абсолютної цілісності. Аналізується нерозривність зв'язків між Сейр і Сулук (вживаються разом; в перекладі з арабського: «спостерігати», «бродити»), їх роль у досягненні божественної любові. Відзначається, що суфізм є вченням про моральність і з цієї причини в період «Сейрі Сулук» Саликом втрачено зв'язок з невіглаством. Щоб долучитися до науки, він відмовляється від поганих справ і знаходить чесноти. Роз'яснюються етапи цих моральних пошуків. Перший етап для Салика становить Сейр i-Іллах, другий - Сейра i-Філлах, третій - Сейра i-маАллах, а четвертий - Сейра i-Аніллах. Автор дає інформацію про умови, необхідні для подолання зазначених етапів. Коли Салик намагається подолати четвертий етап випробувань (Аніллах), ставати реальністю остаточний поворот до касрату. Це відбувається в той момент, коли мандрівник повертається від Аллаха, що докладно аналізується автором. У суфійському вченні «касрат» означає «безліч», тобто протилежність Сдиному. Вказується, що два щаблі з чотирьох, пов'язані з пошуками чесноти, мають характер зближення (араб. «Вели») з Всевишнім, і Салику вдається досягти цього шуканого стану. Тоді як під час двох інших етапів Салик домагається статусу наставника (Муршід). Тут же відзначаються деякі розбіжності в поглядах окремих суфіїв у зв'язку з Сейрі Сулук. Як приклад описуються різні лики Салика, що відбилися в поезії. Дається інформація про допоміжної діяльності Муршід (наставник) в процесі підготовки до Сейрі Сулук. Всуфізме основною місією Сулука є досягнення моменту, в який перед мандрівником відкриваються ворота, що ведуть до осягнення Істини. Але для цього спочатку необхідно добитися вищої досконалості, відмовитися від спокус, придбати ряд позитивних властивостей. У статті вказані способи, дотримуючись яких людина приходить до морального очищення. Підкреслюється, що в суфізмі кількість шляхів, що ведуть до Істини, превалює навіть над числом зірок небосхилу. Виражається думка про те, що мета саликов хоча і має загальний характер, але шляхи досягнення іiі дуже різноманітні. Шляхи ці іменуються «меслек», що означає «ідея». Згідно з суфійським вченням людина є однією 3 частин Творця і з цієї причини він ближчий до Всевишнього, ніж інші істоти. Стаття містить ряд цитат, що підтверджують цю обставину. Ї̈̈ основну суть становить прагнення автора розібратися в правомірності твердження, за яким божественна любов характеризує людину як найдосконалішу з усіх істот. Одночасно підкреслюється, що завдяки своїй чесноти і силі духу він досягає найвищих вершин. Це сходження реалізовується за рахунок відчутних уявних і духовних зусиль. За уявленнями тюркських суфіїв XIII-XV століть про такі матерії, як любов i чеснота, можна виявити деяку типологічну подібність 3 поглядами класиків східної літератури. Це дозволяє дійти спільного висновку, а також простежити подібні та відмінні риси з порушеної теми. 3 огляду на те, що любовна тематика увібрала в себе як мирське буття, так і елементи Ірфана (особливий вид сакрального знання в ісламі про те, як наблизитися до Аллаха), надається можливість більш грунтовного спостереження за тернистим шляхом Салика, який поступово віддаляється від непорядних справ і знаходить світлий розум. Це внутрішнє перетворення людини, своєрідний контраст між двома полярними станами душі і єства залучається автором статті до відповідного аналізу.

На шляху до очищення Салик насамперед зарікається, в зв'язку з чим з його вуст звучать думки певного характеру. Для прояснення своєї позиції автор звертається до прикладів з творчості поетів-суфіїв і висловлює особисту думку щодо зазначеного питання.

Загалом у статті міститься багатий матеріал щодо внутрішнього світу Салика, спонукань, що підштовхують його до очищення і Сднання, протидії різного роду спокусам.

Ключові слова: Сулук, Салик, мораль, суфізм, розум, єдність, тіло. 